\title{
REVEALING THE DECLINE AND EXPANSION OF ORCHIDS OF NW EUROPEAN RUSSIA
}

\author{
PETR G. EFIMOV
}

Herbarium, Komarov Botanical Institute of the Russian Academy of Sciences, Prof. Popov str. 2, Saint-Petersburg, 192288, Russia. E-mail: efimov81@mail.ru, efimov811@hotmail.com; Tel. and Fax: +78123460839

\section{ABSTRACT}

A new approach to reveal the dynamics of taxa on incompletely investigated territories was developed. The decline/expansion rate of orchids in the North Western part of European Russia (Leningrad, Novgorod and Pskov Regions, an area approx. 195,000 km²) was estimated using this method. The method is based on comparison of numbers of grid cells where a certain species was recorded in various time intervals using specially designed software. More than 9000 records were used, however the territory remained insufficiently and unevenly studied both spatially and over time. The study revealed a statistically significant $(p<0.01)$ decrease for Coeloglossum viride, Corallorhiza trifida, Cypripedium calceolus, Gymnadenia conopsea, Herminium monorchis, Malaxis monophyllos, Neotinea ustulata and Orchis militaris and a significant increase for Dactylorhiza baltica, D. fuchsii and Platanthera chlorantha. In several taxa, the trend was changed over the time. Of them, Gymnadenia conopsea displayed significant decline only since the middle of XX century, and Orchis militaris and Epipactis atrorubens decreased significantly only in the end of XIX and the beginning of XX century. The reasons for these patterns of dynamics were discussed. Parallels between the dynamics of orchids and land use in different periods of time in Russia are provided.

Keywords: Orchidaceae, dynamics of plant species, North-West European Russia

\section{Introduction}

The decline or expansion of plant species range and population size is an integral part of the evolutionary process. The increasing influence of anthropogenic factors on habitats essentially affected the vector of evolution in many groups of plants adapting to new environment formed by humans. As a result, some taxa are increasing and diversifying, while others decrease dramatically. Technical progress over the last 150 years provides new anthropogenic factors affecting nature. Large number of records, herbarium and literature data collected during last 100-200 years allow the changes in species distribution in response to the changing environment to be traced. This analyses is very important for biodiversity conservation issues.

Family Orchidaceae contains many species declining in response to the changing environment and therefore deserves particular interest from the nature conservation point of view. Various reasons for orchid decline were widely reviewed in the literature, e.g. by Dixon et al. (2003). The main reason for orchid decline is thought to be the loss of habitats in changing landscapes, climate and agriculture. Direct collection of plants in the wild is also an important factor which has driven many species to almost complete extinction in nature. Therefore orchid species are widely used as indicators in studying plant decline in natural habitats.

The aim of the present study was to investigate the dynamics of the orchids of North-West European Russia ('NW-Russia' for short in the text below). The concerned territory covers an area approx. 195,000 sq. km and includes 4 administrative units: the city of Saint-Petersburg, Leningrad Region, Pskov Region and Novgorod Region. Ten of 28 orchids, native to NW-Russia are included in the Red Data Book of Russian Federation (Bardunov and Novikov 2008) and 14 species are listed in the Red Data Book of Leningrad Region (Tzvelev 2000). In the latter, information about species decline was provided only for Calypso bulbosa and Orchis ustulata. In Leningrad Region, the number of locations of the former species reduced from at least 4 to 1 , bringing the taxon to the brink of extinction. The latter species also decreased drammatically. The dynamics of other orchids in this Red Data Book was not analysed, and species were assigned to various categories (not IUCN-based) mainly depending on their rarity. However data about species dynamics are important for the assessment of species to the Red List categories, as for example it is delineated by IUCN criteria B and C (IUCN 2001). Correspondingly, the data on the dynamics of the orchids for the considered territory are important and may be used in future in the preparation of the documents which regulate the nature conservation in the studied area.

Level of floristic exploration of the considered territory is relatively low, which is more or less typical for European Russia. Moreover, the territory is unevenly investigated both over time and geographically. Thus, central part of Leningrad Region and Karelsky Isthmus are studied better than the rest of the territory, and Novgorod Region is studied most poorly. Large areas throughout this have no records of plants distribution. This study demonstrates 
the possibilities of the use of incomplete data to reveal species' dynamics and might also provide some factual data for plant conservation in Russia. Grid mapping was applied as a main tool for studying dynamics of plant distribution. It is widely used in biogeography for such purposes as for assessing the taxonomical richness, biodiversity hotspots, potential areas of vegetatation alliances, defining biogeographical zones, identifying correlations between distribution of taxa and ecological factors etc. (Humphries et al. 1999; Schönfelder 1999 etc.). The implications of grid mapping for plant conservation is also very significant.

However, many countries do not possess generally accepted databases for accumulation data on plant distribution. Russia is such an example on European continent (Tikhomirov 1999). Floristic data are located in herbarium collections and the vast literature with only small part being accumulated in local floras and databases, including GBIF. Very few floristic investigations with regular mapping have been undertaken across any Regions of Russia, except for Vladimir Region (Seregin 2004). Consequently, the need for exact data on species dynamics should be satiated from the occasional records from herbarium collections and literature, without regular data of the kind that were collected for neighbouring Finland (Kurtto and Lampinen 1999), Estonia (Kukk and Kull 2005) and many other more thoroughly studied territories.

\section{Materials and methods}

\section{The sources of data}

The main source of the data was a database 'Orchids of North-West European Russia' held at Komarov Botanical Institute, Saint-Petersburg which includes all data available from herbarium collections, literature and personal observations in nature (Efimov 2010). It was associated with Apache, PHP and PostgreSQL (Geschwinde and Schoenig 2002) and allows counting the number of grid cells for any selected time intervals (accessible via internet from URL: http://www.nwr-orchids.ru/). The grid system used for this study is based on the coordinate system with the length of every grid cell 12 minutes longitude and 6 minutes latitude, with the area approx. $100 \mathrm{sq} . \mathrm{km}$, becoming smaller to the north. The numbers of grid cells

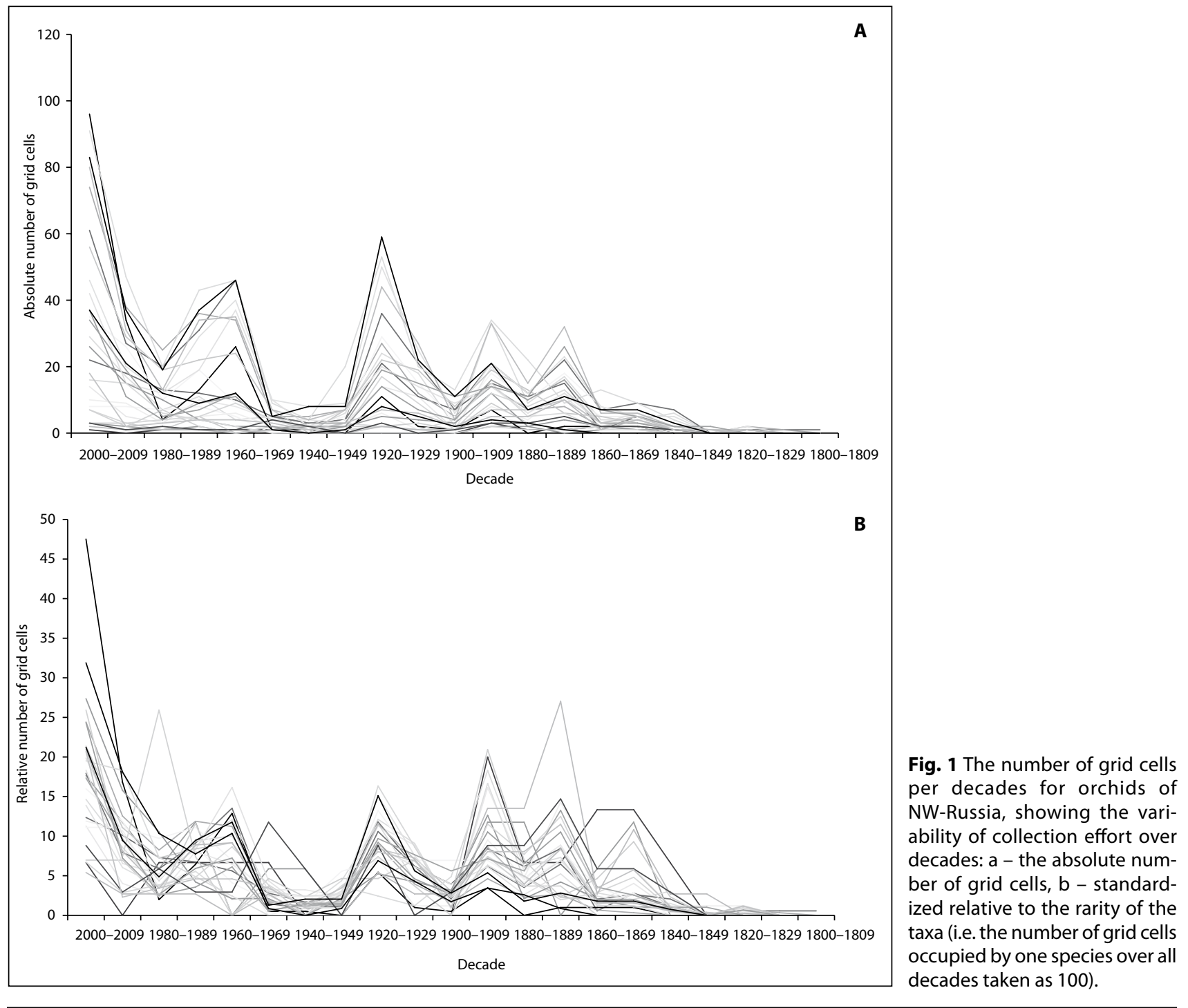

European Journal of Environmental Sciences, Vol. 1, №. 2 
Decline and expansion of orchids $\quad 9$

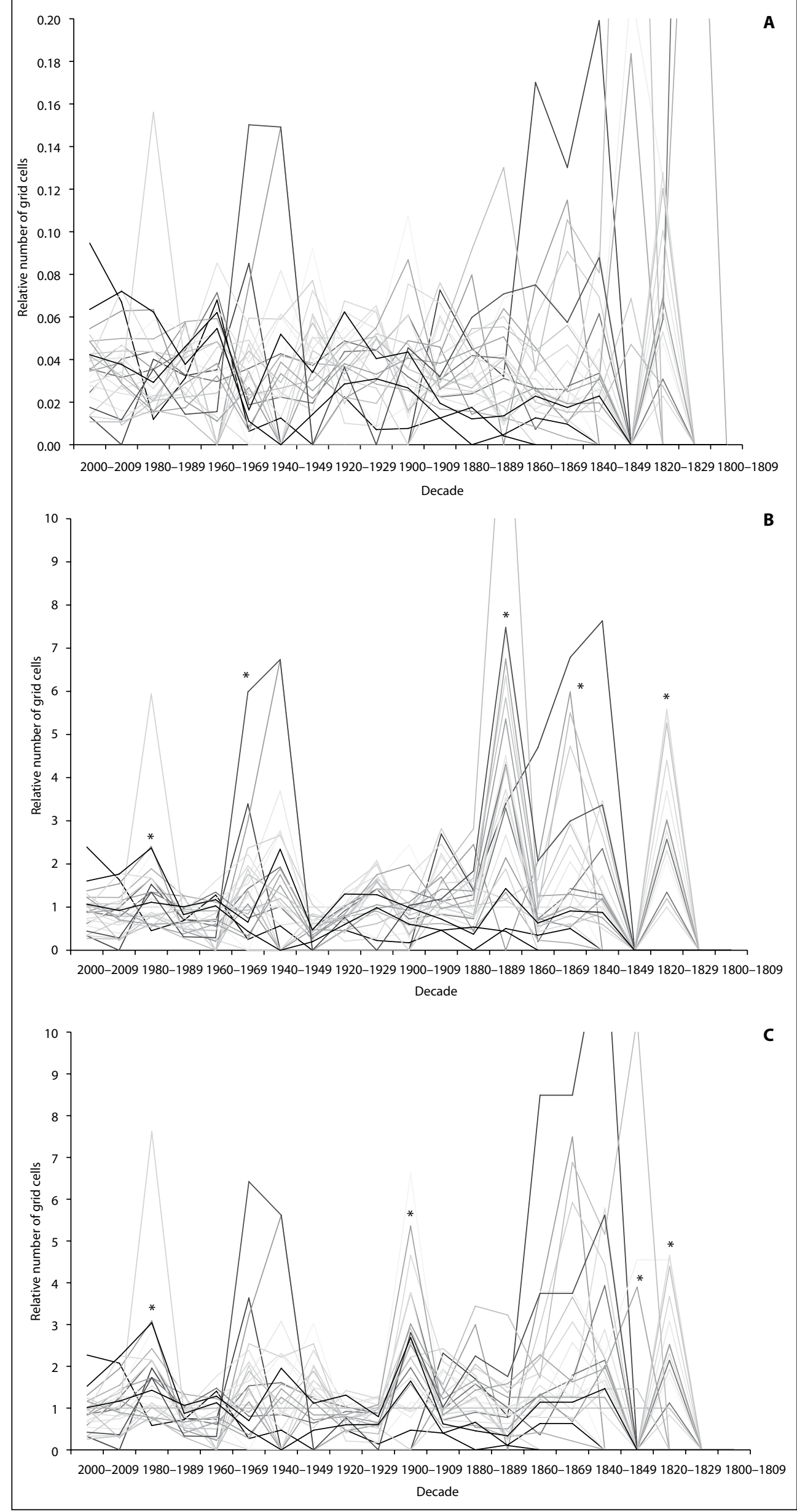

Fig. 2 The number of grid cells per decades for orchids of NWRussia, standardized relative to the rarity of the taxa and collecton effort: a - coming from the hypothesis that all orchid pecries as a whole do not change their abundance over time, $\mathrm{b}$ - coming from the hypothsis that Dactylorhiza maculate does not change its abundance over time, c - coming from the hypothesis that Lister ovate does not change its abundance over time.

European Journal of Environmental Sciences, Vol. 1, №. 2 


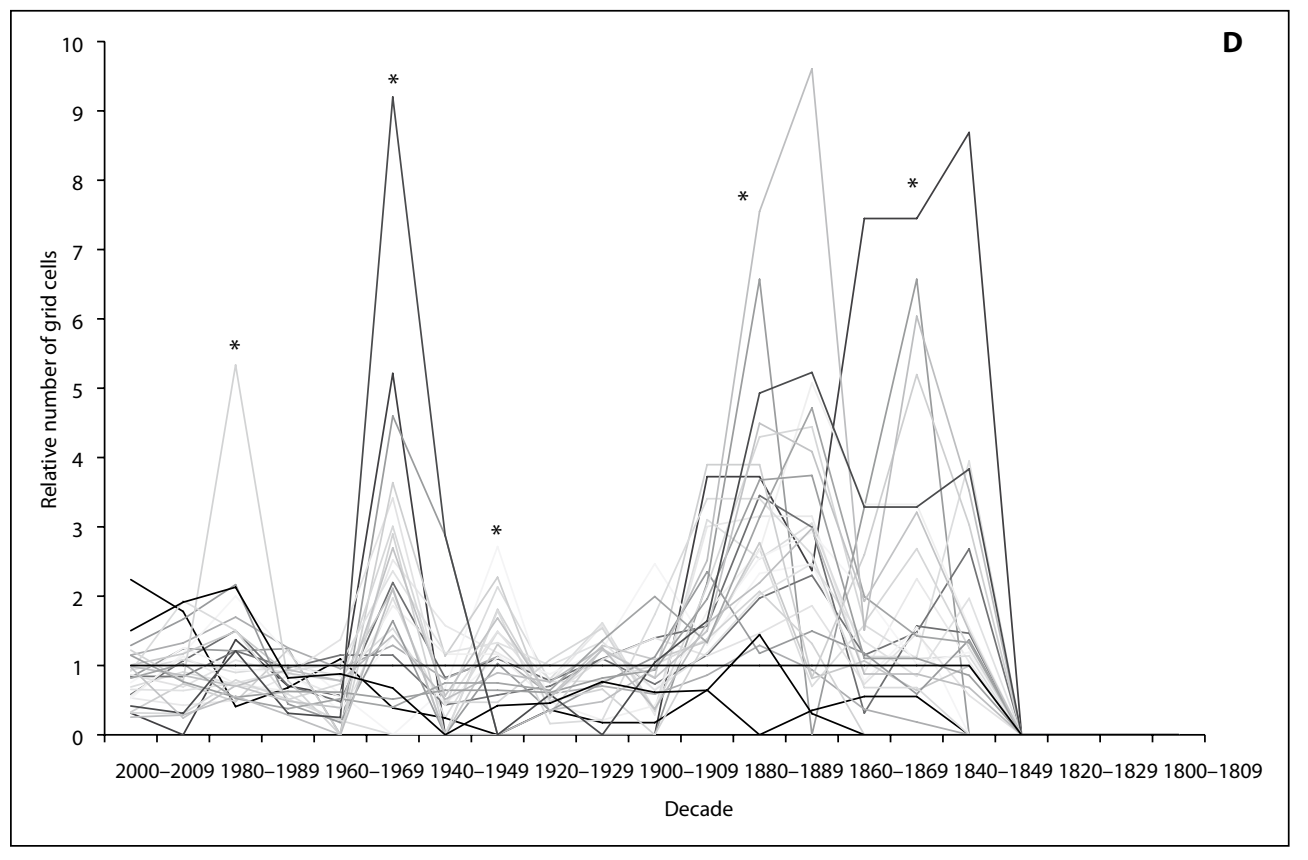

Fig. $2 \mathrm{~d}$ - coming from the hypothesis that Platanthera bifolia does not change its abundance over time. Asterisks $(*)$ mark decades where the collection effort standardization proves to be especially incorrect. recorded in different periods of time were further used for assessing the dynamics of the taxa and for comparison with the data from other countries.

To compare the dynamics of orchids of NW-Russia with other countries, we also used the comparable data on the numbers of grid cells for Estonia (1921-1970 and 19712004) and United Kingdom (1930-1969 and 1987-1999). Those data were taken from Kull and Hutchings (2006).

\section{Mathematical background}

The method used here for elucidation the species' dynamics was based on the comparison of the numbers of grid cells recorded in two time intervals. Original data for NW-Russia are accessible from http://www.nwr-orchids .ru/. As no time intervals contained complete data, and the intensity of botanical exploration of the territory was different in various time periods, the number of grid cells was standardised according to the intensity of collection effort. The variation of collection effort in not-standardized data sets is illustrated at Fig. 1. It is clear that in the nineteenth century and in 1930-1960 period floristic exploration of NW-Russia was many times lower than in 1920s or after 1960 .

So the evaluation of the collection effort is a crucial point for this study. We proposed 2 ways of standardization:

1) Coming from the hypothesis that all orchid species as a whole do not change their abundance over time;

2) Coming from the hypothesis that a certain species does not change its abundance over time. Dactylorhiza maculata, Listera ovata and Platanthera bifolia were tested as the most suitable candidates to this role, as they do not perform noticeable decrease or increase (evaluation 'by eye'), and represent abundant taxa, widely represented in many collections from any corner of NW-Russia.
The standardization procedure was included into the statistical test itself (see below). The illustration of how the standardization influence the data used for analysis is shown in Fig. 2 with 10-year long time intervals. The first method of standardization (Fig. 2a) doesn't take into consideration the fact that all orchids in general might decrease, as it was found by Kull and Hutchings (2006: 33). If this is true, this method might give more optimistic results. The independent use of the second standardization method would solve this problem, if the species used in it would show slight increase when using the first method of standardization. However, the second method of standardization (Fig. 2b-d) shows some cases of incorrect evaluation $\left({ }^{*}\right)$ due to stochastic reasons of over- or under-collection, but this should not be important on longer time intervals, including 30-year long periods which we used for this study.

There exist several statistical criteria for identifying decline in threatened species using museum data. These include Solow equation, trend analysis (the correlation between number of registrations and time) and other methods (McCarthy 1998). For this study we tested a standard Pearson's chi-square test, as a statistical criterion for identification of the changes in the quantity of the grid cells occupied in different periods of time:

$$
\mathrm{X}^{2}=\frac{\left(O_{1}-E_{1}\right)^{2}}{E_{1}}+\frac{\left(O_{2}-E_{2}\right)^{2}}{E_{2}}
$$

where $O_{1}$ and $O_{2}$ represent observed frequencies (number of grid cells) in both compared time intervals, $E_{1}$ and $E_{2}$ - corresponding expected frequencies, asserted by the null hypothesis that there was no change in the number of grid cells through time.

In the rare cases of very low numbers of cells occupied by species $(<5)$ we did not run chi-square test. The 
collecting effort was taken into consideration when calculating the expected frequencies:

$$
E_{1}=\left(O_{1}+O_{2}\right) \times k_{1} \text {, and } E_{2}=\left(O_{1}+O_{2}\right) \times k_{2} \text {, }
$$

where ' $k$ ' is a coefficient of collecting effort in two periods of time analyzed $\left(k_{1}+k_{2}=1\right)$. Calculating the coefficient of collecting effort by both methods was performed according to the following formulas:

$$
\begin{aligned}
& k_{1}=\frac{N_{1}}{N_{1}+N_{2}}, \text { and } \\
& k_{2}=\frac{N_{2}}{N_{1}+N_{2}},
\end{aligned}
$$

where $N_{1}$ and $N_{2}$ are the numbers of grid cells in the periods of time compared, occupied either by all orchid species or only by Dactylorhiza maculata, Listera ovata or Platanthera bifolia, depending from the method of collecting effort standardization.

To understand the general dynamics of the orchids for NW-Russia, we compared the numbers of grid cells in 1770-1949 and 1950-2010. To understand the changes of the dynamics of orchids of NW-Russia, we compared several shorter periods pair wise: 1770-1889, 1890-1919, 1920-1949, 1950-1979, 1980-2010. To compare the data from NW-Russia with those which exist for Estonia and United Kingdom, we compared 1921-1970 with 1971-2004 for NW-Russia and Estonia and 1930-1969 with 1987-1999 for United Kingdom.

However, the collection effort estimation method is very sensitive to the level of floristic exploration of the territory. If the territory is studied more or less completely during the survey period, and the data in major part represent the results of the revisitation fieldwork, collection effort may be estimated incorrectly. It means that for the territories which are better explored, smaller time intervals are needed for the correct comparison, as it is the case with Great Britain or Estonia.

Vice versa, the territories with low level of floristic exploration, as NW-Russia, should be analyzed on longer time intervals. If the time intervals are short, they do not give enough representative data for species which are not abundant. With the data set from NW-Russia, we found that when the intervals were shorter than 30 years the data became insufficient for the most of the taxa to obtain statistically significant results with chi-square test.

\section{Results}

\section{The general dynamics of orchids of NW-Russia}

For understanding the general dynamics of orchids of NW-Russia, we took into account the whole data set, dividing it on 2 periods at the year 1950 (table 1).
In general, all methods of standardization of collection effort showed similar results. High probability of decrease (>99\%) was shown for Coeloglossum viride, Corallorhiza trifida, Gymnadenia conopsea, Herminium monorchis, Malaxis monophyllos and Neotinea ustulata. The decrease of Orchis militaris oscillates from $>99 \%$ to $95-99 \%$ depending on the method of standardization, and the decrease of Cypripedium calceolus oscillates greatly from $90-95 \%$ to $>99 \%$. The majority of methods also show significant decrease (with probability $>90 \%$ ) for Epipogium aphyllum and Neottia nidus-avis. Standardization based on the stability of Dactylorhiza maculata and Platanthera bifolia also showed significant decrease of Dactylorhiza traunsteineri, Epipactis atrorubens and E. helleborine, thus showing the most pessimistic value. The standardization based on the stability of Listera ovata in general gave more optimistic data, similar to standardization coming from hypothesis that all orchids in general are stable.

However, some species showed highly significant signal of their increase in number, viz. Dactylorhiza baltica, D. fuchsii and Platanthera chlorantha. Probability of their increase $>99 \%$ was detected by all methods of standardization. The highest chi-square value (66.5) was found for Dactylorhiza baltica, corresponding to as low probability of the null hypothesis (which stands for the stability of this species) as $5.5 \times 10^{-16}$. Some increase of Hammarbya paludosa, found by 'optimistic' methods of standardization, most probably represents an artifact and would be discussed later.

\section{A small-scale dynamics of orchids of NW-Russia}

The results of pair wise comparison of 30-year long time intervals (1770-1889 and 1890-1919, 1890-1919 and 1920-1949, 1920-1949 and 1950-1979, 1950-1979 and 1980-2010) suffered from stochastic oscillations of the amount of data in different decades, resulting in contradictory results by applying different standardization methods. However some general conclusions could be made.

On average, two earlier time periods show high percent of decreasing taxa. Mostly those are species that perform general decline (see above). Vice versa, the increase was found mostly during the later periods. Apart from Dactylorhiza baltica, D. fuchsii and Platanthera chlorantha that perform increase in all intervals, those species are Corallorhiza trifida, Hammarbya paludosa, Liparis loeselii, Listera cordata, Malaxis monophyllos. All those taxa are small green-flowered inconspicuous herbs, and their increase in last decades is probably an artifact of their more intensive search. The 'increase' of Hammarbya paludosa is most probably due to the intensification of vegetation studies in the bogs of NW-Russia by M. S. Botsch and her colleagues. The 'increase' of Liparis loeselii is most probably connected with the intensive exploration of the flora of Pskov region in the end of XXth century, where the majority of records of Liparis were made. 


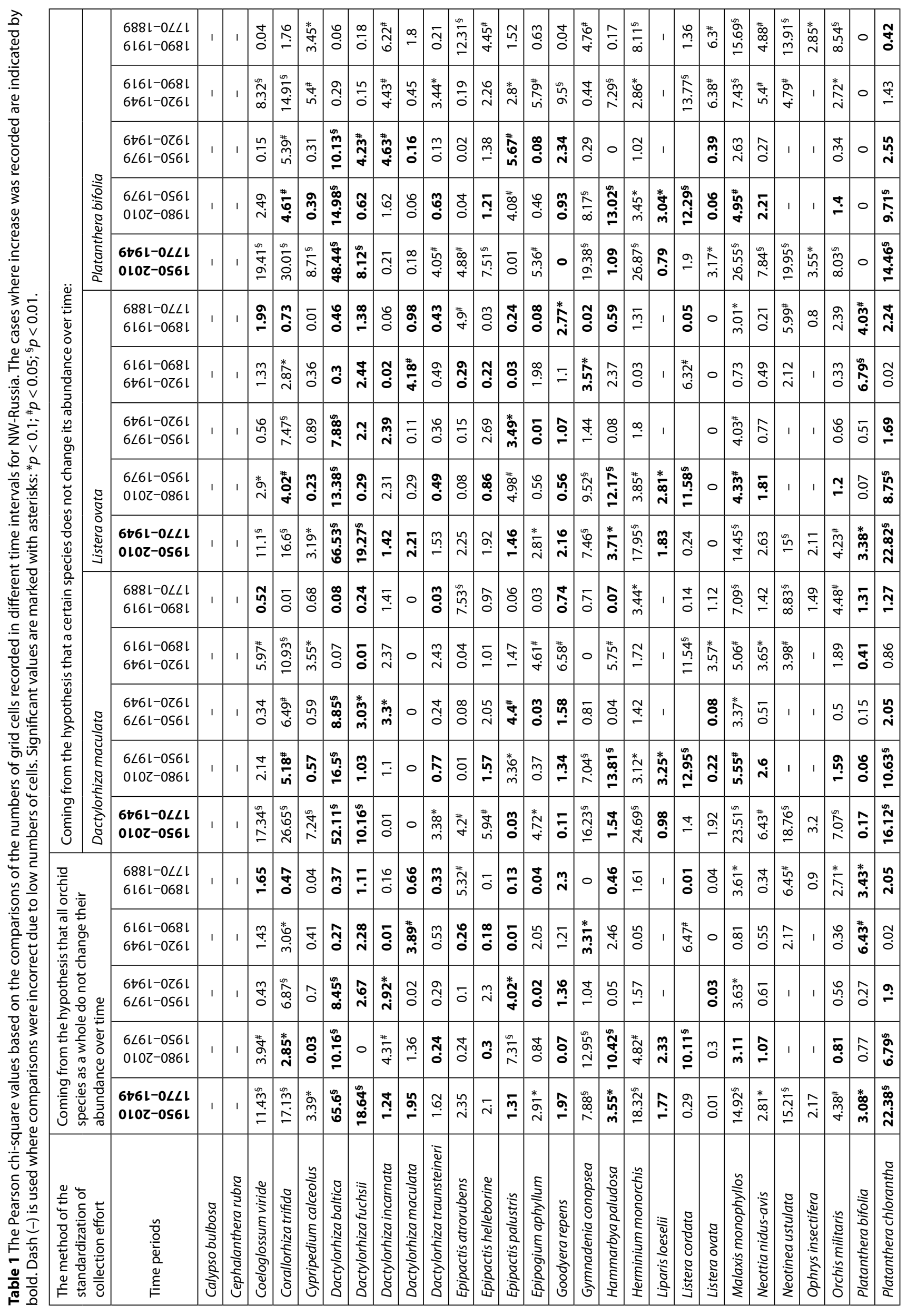


However, in some cases the change in the dynamics from earlier to later time periods might be detected. This might be suspected for Corallorhiza trifida, Epipactis atrorubens, Gymnadenia conopsea, Hammarbya paludosa, Listera cordata, Malaxis monophyllos and Orchis militaris. Of them, only Gymnadenia conopsea displays decrease (and very strong) in the recent decades. This well corresponds to the direct observations of the florist botanists 'by eye'. Corallorhiza trifida, Hammarbya paludosa, Listera cordata and Malaxis monophyllos display increase in the latest decades, which might be again an artifact of the over-collection of rare species, although the possibility exists that low industry rates of the last decades might provide a positive influence on the flora. Epipactis atrorubens and Orchis militaris display decrease in the earliest periods of observations, which was not confirmed in later periods. This is probably an important indicator of true dynamics of those species.

\section{A comparison with Estonia and United Kingdom}

Here the same methods were utilized for the analysis of the dynamics within 1920-2004 (1930-1999 for United Kingdom) (table 2). Unfortunately the results are often contradictory when applying differents methods of standartization and consequently almost no general tendencies were resolved. The only exceptions are the increasing species - Dactylorhiza baltica, D. fuchsii and Platanthera chlorantha. Of them, D. fuchsii displays significant increase in all 3 countries, significantly confirmed almost by any method of standardization, whereas D. baltica and Platanthera chlorantha exhibits increase only in NW-Russia and Estonia (D. baltica is absent in the flora of British Isles). Also Cephalanthera rubra, Dactylorhiza traunsteineri, Epipactis atrorubens and Epipogium aphyllum agree with each other in low number of any significantly detected tendencies.

I suppose that the contradictory results discovered by this comparison reveal inappropriate use of the method for territories with high level of floristic exploration. When the territory is more or less completely studied, the number of cells ceases to grow in response to further intensification of collection effort, and the standardization of collection effort became inappropriate. In this case either absolute number of grid cells should be compared, as it was done by Kull and Hutchings (2006), or smaller time intervals selected, if possible. Vice versa, the territories with low level of floristic exploration, as NW-Russia, should be analyzed on longer time intervals. If the time intervals are short, they do not give enough representative data for species.

\section{Discussion}

The decline of orchids is well-known (Pritchard 1989; Dixon et al. 2003) and probably is more prominent than in any other large family of vascular plants. The main factor of decrease is thought to be the loss or alteration of the habitats to which they are accustomed to, although many other factors are known to exist. Many large-flowered species are prone to massive extirpation by commercial collectors and amateurs. With orchids, habitat loss is critical, because many orchids are characterized by narrow ecological range, mycotrophy, long ontogeny, entomophily etc. General climate change, whether anthropogenical or not, also may be an important factor for decrease of certain species.

The same reasons may act for decline of the orchids of NW-Russia. The majority of orchids of NW-Russia are growing at the edges of meadows, at the forest glades and similar places. The migration of orchids to NW-Russia within last 10,000 years, after the glaciation period was over, might have been connected with the migration of people or wild grazing animals, which promoted the formation of meadow-like habitat types.

High rates of decline in 2 earlier periods of observation might reflect the negative influence of moving from traditional agriculture based on family farming to collective farms. The collectivization of the farm sector, which took place in Russia in 1920s-1930s was responsible for changes in the flora of meadows, which include many orchids. Individual fields were united into collective farms, named 'kolkhoz' or 'sovkhoz', which were quickly tilled by agricultural machines. The small glades, with independent regime of mowing or pasturage with diverse flora were either abandoned or included into collective farms. On the other hand, the general industrialization that began in the end of XIXth century might have influenced orchids, challenging climatic change or chemical pollution.

Low decrease of orchids of the later periods might indicate some stabilization of the environment. In the last decades of 'new Russia' any agriculture within NW part of our country has mostly ceased. This led to the abandonment of fields and their subsequent eutrophication and (or) afforestation. This doesn't give any opportunities for meadow species of orchids to survive, the same as during total land ploughing during the Soviet times.

The increase of many orchids found in later periods is, as it was described before, mainly an artifact. However, this does not concern Dactylorhiza baltica, D. fuchsii and Platanthera chlorantha, whose strong increase was found to be statistically significant by all methods used in the study. To explain the progress made by those species, a separate investigate should be done. However, some hypotheses could be proposed. Possibly, the increase of this species reflects the evolutionary process which leads to the formation of micro-taxa which are better adapted to the modern environment, combined with strong selection pressure from high competition between herbs, spring fires and chemical pollution. 


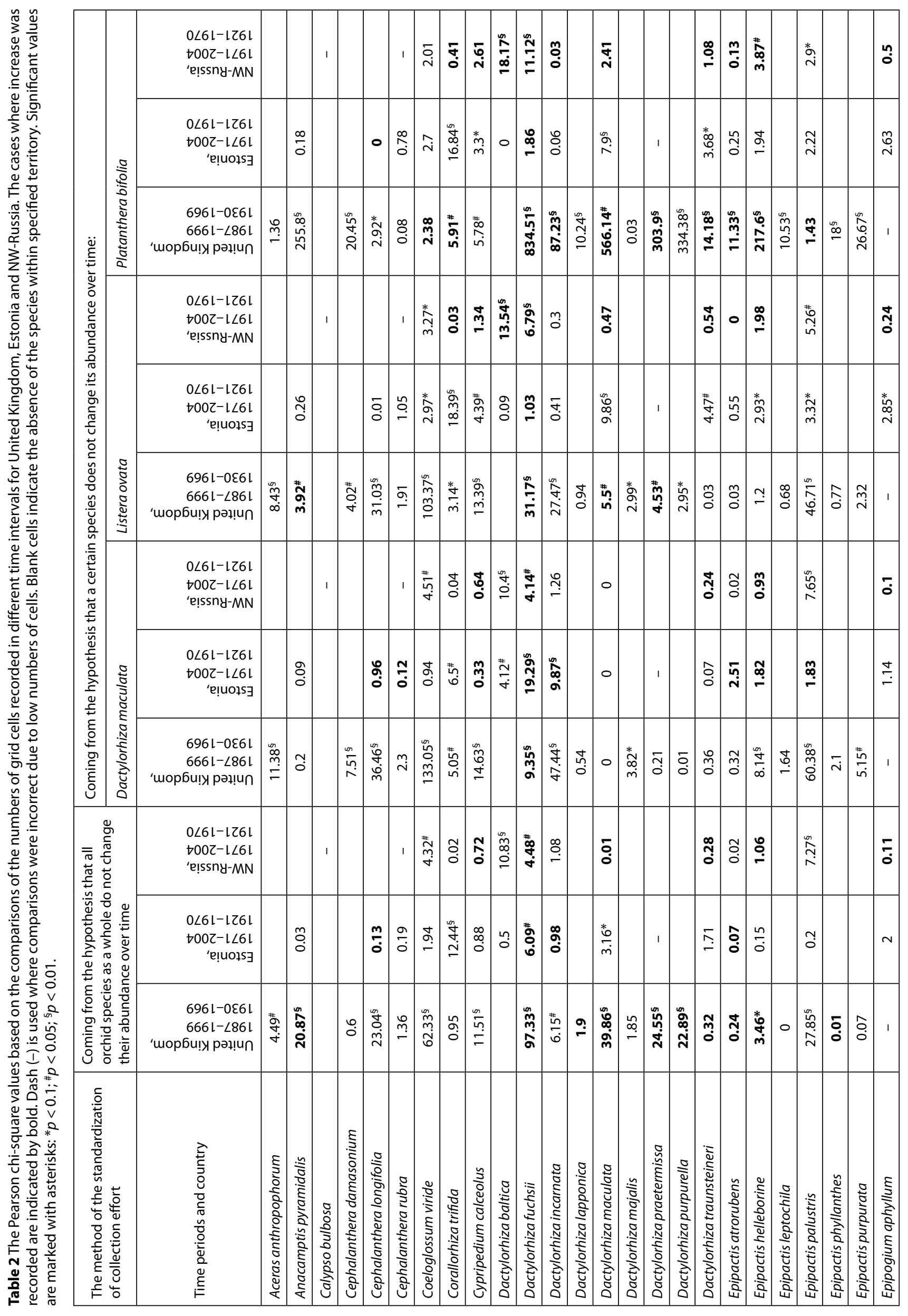




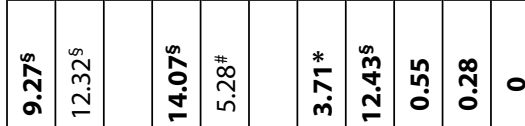
$\circ \quad 0 \quad \begin{array}{lll}\frac{m}{4} \\ 0\end{array}$

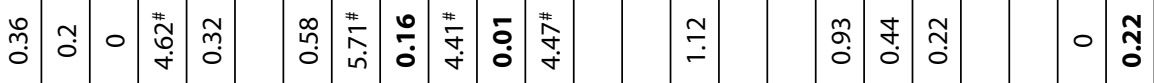

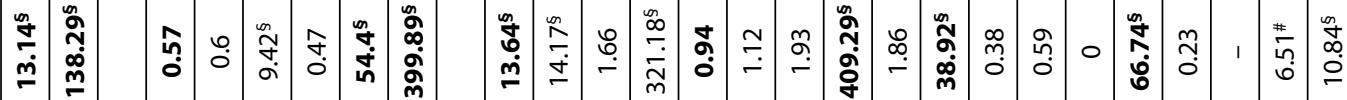

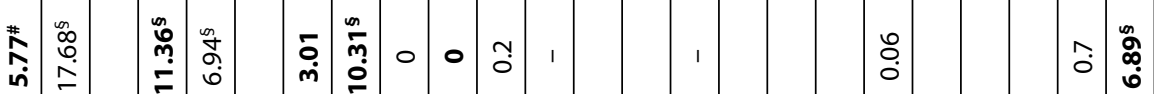

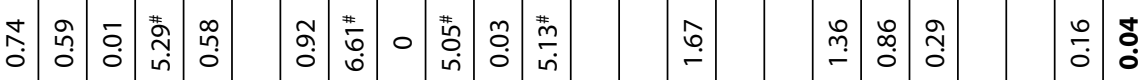

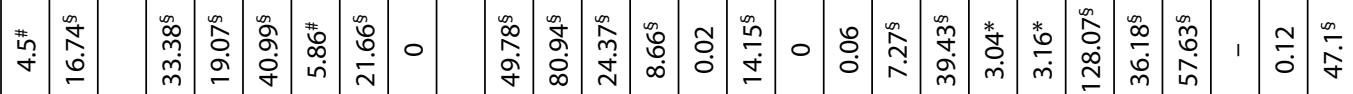

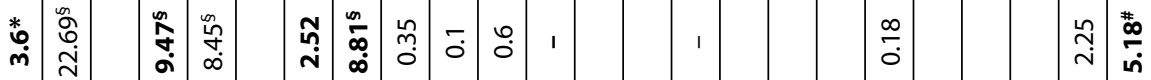

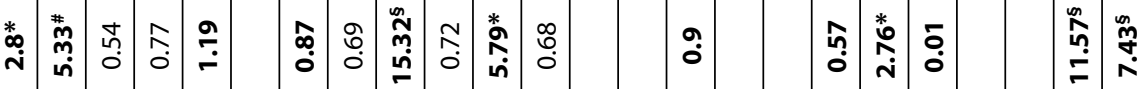

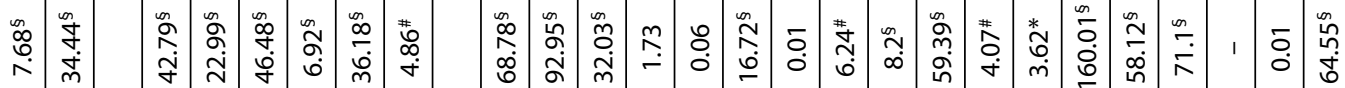

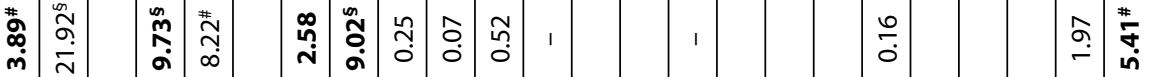

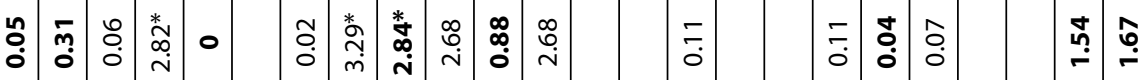

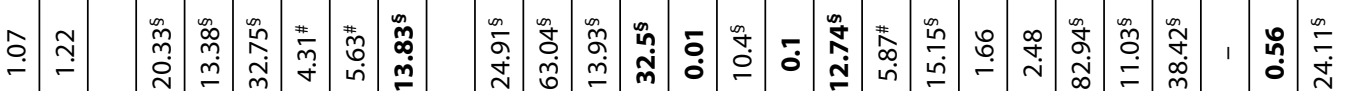

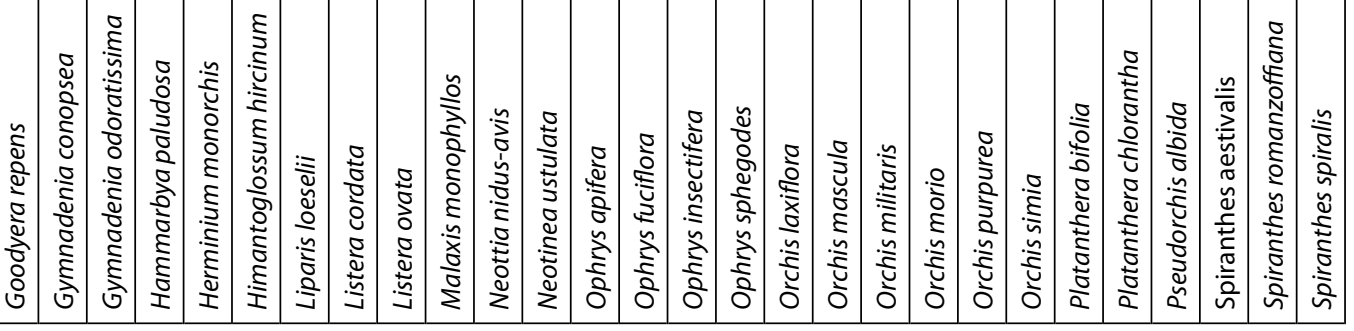


Dactylorhiza baltica is an allotetraploid species (Shipunov et al. 2005) and speculatively, taking into account its increasing rates, it might have been formed via hybridization quite recently (Efimov 2011) - in the last hundred (or hundreds?) of years. Nowadays $D$. baltica seems to be the commonest orchid in the southern half of NW-Russia, e.g. across all of the Pskov Region, where it inhabits almost every meadow. Along with Platanthera chlorantha, it can persist well in dense herb stand following eutrophication and also in anthropogenically disturbed habitats, for example, along railways between rails within Saint-Petersburg. In NW-Russia the species grows on its north-eastern distributional limit, which has been clearly enlarged nowadays, because all records near its distributional limit were made recently.

Platanthera chlorantha occurs commonly on the meadows representing different stages of afforestation, which are rather common nowadays within NW-Russia. $P$. chlorantha is most common in Leningrad and Novgorod Regions, and has clearly enlarged its distributional limit to the north and east. E.g., all records of this species in the west Leningrad Region were made in the Twenty first century. It can be speculated that this species might be represented by some special microtaxon native to NW-Russia and maybe to some surroundings, which may successfully withstand the competition with other herbs. This speculation is based on the genetic study where $P$. chlorantha proved to be almost indistinguishable from closely related $P$. bifolia (Bateman 2006), and consequently one may speculate whether $P$. chlorantha is a one monophyletic lineage or it represents several independent microtaxa.

Dactylorhiza fuchsii is the only species which display increase in NW-Russia, Estonia and United Kingdom according to this study. This fact may reflect either some evolutionary processes within the genus Dactylorhiza or may be due to some favorable ecological conditions for this species that exist nowadays.

Decrease of orchid species in forest habitats (Corallorhiza trifida, Malaxis monophyllos, Epipogium aphyllum and Neottia nidus-avis) might be influenced by depleting of primary forests, although it might also reflect a result of multi-factored changes of soil microflora, pollution, climate, changes of tree composition in the forest and so on. The decrease of Cypripedium calceolus may be also caused by extirpation by people, especially in small populations.

Last but not least, several notes should be added concerning taxa which has not undergone statistical analysis due lo low number of cells where they occur: Calypso bulbosa and Cephalanthera rubra. Calypso is the rarest orchid of NW-Russia, and its dynamics are clear without statistical comparison. 4 localities of this species were known before 1900, and only one persisted up to XXth century. In this last locality a population has undergone a severe reduction in the number of individuals from hundreds of flowering specimens in 1960s to only
31 specimens observed in 2010 with only 8 flowering plants with only one fruit was finally formed that year. Cephalanthera rubra is also very rare and it was recorded only in 5 grid cells. Hopefully, in the majority of cells the plant still exists, although some smaller localities disappeared, especially ones that were situated near the villages. Additional observations are needed to determine whether this species is decreasing in NW-Russia or not.

\section{Acknowledgements}

The study is supported by the Ministry of Education and Science of the Russian Federation (contracts 16.518.11.7071 and П912). My sincere thanks are due to Dmitry Britskiy for programming and for Saint-Petersburg Orchid Society for help during the field work. Special thanks are due to Michael Dodd for improving the language.

\section{REFERENCES}

Bardunov LV, Novikov VS (2008) Red data book of Russian Federation. Товарищество научных изданий КМК, Moscow.

Bateman RM (2006) How many orchid species are currently native to the British Isles? In: Bailey JP, Ellis RG (eds) Current taxonomic research on the British and European flora. BSBI, London, pp 89-10.

Dixon KW et al (eds) (2003). Orchid conservation. Natural History Publications, Kota Kinabalu, pp 1-24.

Efimov PG (2010) The dynamics of Orchids of NW European Russia. J Eur Orch 42: 501-518.

Efimov PG (2011) Orchids of North-West European Russia (Leningrad, Pskov and Novgorod regions). Товарищество научных изданий КМК, Moscow.

Efimov PG, Konechnaya GY (2008) Orchids of Pskov Region (NWRussia). J Eur Orch 40: 335-362.

Geschwinde E, Schoenig H-J (2002) PHP and PostgreSQL Advanced Web Programming. SAMS, Indianapolis.

Humphries C, Araújo M, Williams P et al (1999) Plant diversity in Europe: Atlas Florae Europeae and WORLDMAP. Acta Bot Fenn 162: 11-21.

IUCN Red List categories and criteria: Version 3.1 (2001) IUCN, Gland and Cambridge.

Kukk T, Kull T (2005) Atlas of the Estonian flora. Estonian University of Life Sciences, Institute of Agricultural and Environmental Sciences, Tartu.

Kull T, Hutchings MJ (2006) A comparative analysis of decline in the distribution ranges of orchid species in Estonia and the United Kingdom. Biol Cons 129: 31-39.

Kurtto A, Lampinen R (1999) Atlas of the distribution of vascular plants in Finland - a digital view of the national floristic database. Acta Bot Fenn 162: 67-74.

McCarthy MA (1998) Identifying declining and threatened species with museum data. Biol Cons 83: 9-17.

Pritchard HW (ed) (1989) Orchid conservation. Cambridge University Press, Cambridge.

Seregin AP (2010) Expansions of plant species to the flora of 
Vladimir Region in the last ten years. Botanicheckij Zhurnal 95: 1254-1267.

Shipunov AB, Fay MF, Chase MW (2005) Evolution of Dactylorhiza baltica (Orchidaceae) from European Russia: evidence from molecular markers and morphology. Bot J Linn Soc 147: 257-274.
Tikhomirov VN (1999) Regional problems in plant chorology of European Russia. Acta Bot Fenn 162: 99-102.

Tzvelev NN (ed) (2000) Red Data Book of Leningrad Region 2: Plants and Fungi. Издательство «Акционер и К», SaintPetersburg. 